\title{
Erratum to: An experimental study on the comparison of the effects of triester glycerol oxide on wound repair
}

\author{
Serhat Sezgin $^{1} \cdot$ Metin Sencimen $^{2} \cdot$ Aydin Gülses $^{3} \cdot$ Fevzi Erdemci $^{4} \cdot$ Mustafa Ayna $^{5,6}$. \\ İsmail K. Gider ${ }^{7}$ • Onder Ongoru ${ }^{8}$ • Tuncer Cayci ${ }^{9}$
}

Published online: 28 November 2016

(C) Springer-Verlag Berlin Heidelberg 2016

Erratum to: Oral and Maxillofacial Surgery 20(3): 273-279

DOI 10.1007/s10006-016-0566-1

The original version of the above article misses a reference in the introduction text, after the wording Geckili et al. Complete reference is presented here:

Geckili O, Bektas-Kayhan K, Eren P, Bilgin T, Unur M. The efficacy of a topical gel with triester glycerol oxide in denture-related mucosal injuries. Gerodontology. 2012 Jun;29(2):e715-20. doi: 10.1111/j.1741-2358.2011.00549.x. Epub 2011 Aug 24

The online version of the original article can be found at http:10.1007 /s10006-016-0566-1.

Aydin Gülses

aydingulses@gmail.com

Dental Service, Aksaz Military Hospital, Muğla, Turkey

2 Department of Oral and Maxillofacial Surgery, Gülhane Military Medical Academy, Ankara, Turkey

3 Dental Service, Sarikamis Military Hospital, Sarikamis, Kars, Turkey

4 Dental Service, Tatvan Military Hospital, Bitlis, Turkey

5 Center for Implant Dentistry, Duisburg, Germany

6 Danube University Krems, Krems, Austria

7 Dental Service, Edremit Military Hospital, Balikesir, Turkey

8 Department of Pathology, Gülhane Military Medical Academy, Ankara, Turkey

9 Department of Microbiology, Gülhane Military Medical Academy, Ankara, Turkey 